\title{
展 望
}

\section{自閉症スペクトラム障害の知覚・認知特性と代償能力}

\author{
片 桐 正 敏
}

自閉症スペクトラム障害 (autism spectrum disorder, ASD) の知覚・認知特性の中には、 定型発達者よりも優れるものも存在する。特にASDのある人がもつ細部への注意処理、部分 処理特性は、対人相互交渉では不利に働く可能性がある一方で、膨大な視覚情報の入力を管 理し、調整する適応メカニズムともいえる。本論では、ASD の部分処理特性について、最新 の研究動向も踏まえてどのような議論が行われているかを概観し、部分処理特性の代償的側 面と療育や支援の方向性について論じた。ASDにみられる部分処理特性は全体処理とは独立 したメカニズムであるという近年の知見から、部分処理特性を伸ばすことは社会性を損なう ことにはつながらず、むしろ部分処理の適応的側面にも注目すべきであることが示唆され た。加えて、部分から全体への切り替えの問題に対処することが支援において重要であり、 ひとつの方法として模倣を用いた療育の可能性を示した。

キー・ワード：自閉症スペクトラム障害 代償 部分処理 全体処理

\section{I . はじめに}

自閉症は、多くの病因とさまざまな類縁の病態が 連続し、広範にわたる症候群であることから (Wing, 1997)、近年、自閉症スペクトラム障害 (autism spectrum disorder, ASD）の名称が広く用いられるようになっ た。アメリカ精神医学会が定めた精神障害に関する新 しいガイドラインである DSM-Vでは、広汎性発達障 害に代わり、診断名称がASD に改められた。

ASD の知覚・認知特性や行動特性は、定型発達者の 中にも存在し、連続性がある (Happé, Ronald, \& Plomin, 2006)。Dawson, Webb, Schellenberg, Dager, Friedman, Aylward, and Richards (2002) は、ASD の家族研究や遺 伝子研究にもとづき、定型発達者から連続してみられる ASD の認知特性を、広域表現型（broader phenotype） という概念を用いて説明している。この表現型は、(1) 視線等の顔における動きや特徵の構造的符号化、(2) 対人行動や社会的報酬に対する反応性、(3) 運動の模 倣、(4)宣言的記憶おょび特徵の結合、(5) プランニ ングや認知的柔軟性等の実行機能、(6)言語能力、 特に音韻処理、に分類される。ASD のある人は、多 様な認知・行動特性を含む複雑な臨床像を示すため (VanMeter, Fein, Morris, Waterhouse, \& Allen, 1997)、

浜松医科大学子ぞものこころの発達研究センター
連続性といっても症状の軽重や表現型の有無による単 なる連続性ではなく、スペクトラムで表現されるよう な、なめらかで複雑な連続性であることを考慮すべき である。こうした ASD の複雑な臨床像を発現している 認知レベルでの因子を特定することが、ASDの本質的 な病態・病因解明へと近づくための重要な道筋となる。

定型発達者から連続して存在する ASD の認知特 性は、必ずしも機能低下を示すものばかりではない。 Grandin and Johnson（2005）は、全体よりも人が注目 しない細部に注意を向ける自らの特性が動物と似てい ることに気づき、Grandin はその特性を生かした仕 事を行っている。こうした細部に注目する特性は、 グラフィック分野においても才能を発揮し (Happé, 1999)、文章校正といった細部の誤りを見つける仕事 に適している（Happé \& Frith, 2006)。細部への注意、 および部分処理の特性は、サバンの能力のある人たち の特性とも関係していると考えられている (Mottron, Dawson, Soulières, Hubert, \& Burack, 2006)。

本論では、ASDのある人の優れた認知特性のひとつ である細部への注意処理・部分処理特性について、最 新の研究動向も踏まえてどのような議論が行われてい るかを概観する。これらを踏まえ、部分処理特性の代 償的な側面および ASD のある人への療育や教育支援 を論じる。 


\section{ASD の細部への注意処理特性}

ASD の細部への注意処理特性は、おもに弱い全体 的統合 (weak central coherence) 仮説 (Happé \& Frith, 2006)、元進した知覚機能 (enhanced perceptual functioning) 仮説（Mottron et al., 2006）によって説明 されている。

全体的統合とは、物事の詳細な部分にはあまり注意 が向けられず、代わりに要点や全体を優先的に処理す る、といつた定型発達の人がもつ認知バイアスであ る。全体的統合が弱いと、全体的構成やつながりの意 味（全体への統合）に対して注意を配分せず、代わり に物事の細部の特徵を優先的に処理し続ける細部集中 型の情報処理（detail-focused processing）が行われる とされる (Happé \& Frith, 2006)。部分処理特性は、積 木模様課題を実施する上で有利に働くことから（Shah \& Frith, 1993)、それはむしろ ASD の一特性として 捉えられている (Happé \& Frith, 2006; Mottron et al., 2006)。さらにASD は全体処理も行えることから (Plaisted, Swettenham, \& Rees, 1999)、ASD の部分処 理特性は全体処理の機能不全によるのではなく、全体 処理の減衰、もしくは優れた部分処理によるものと考 えられている (Happé \& Booth, 2008; Wang, Mottron, Peng, Berthiaume, \& Dawson, 2007)。このように ASD の部分処理特性は、認知スタイルのひとつと捉えるこ とができ、広域表現型の新たな有力候補とされている (Bölte \& Poustka, 2006; Happé, Briskman, \& Frith, 2001)。

克進した知覚機能仮説は、同様に ASD の部分への 優先性を指摘しているが、この優先性は低次の知覚制 御の優越の結果であるとしている。特にこの仮説で は、ASDのある人は全体的な情報処理の障害はなく、 低次知覚が充進した結果であるとする。ASDのこうし た知覚的な特徵は、ポジティブな兆候の一部でもあ り、ASD を理解する上では有効であると Mottron et al. (2006) は主張している。

全体への統合の欠如、もしくは部分処理特性は、 Iarocci, Burack, Shore, Mottron, and Enns (2006) も指 摘している通り、対人相互交渉では不利に働き、さま ざまな知覚文脈を用いるのをより難しくしている可能 性がある。その一方で、ASD のある人にとつて部分 処理特性は、膨大な視覚情報の入力を管理し、調整 するための適応メカニズムともいえる (Iarocci et al., 2006)。別な見方をすれば、刺激の特定部分へ注意を 向けることで数多くある視覚情報の入力を制限し、情 報処理負荷を減少させているともいえる。
両仮説の共通点は、すでに全体よりも部分を指向す るバイアスが生得的に存在し、それが神経発達を非定 型な方向へと導く、というものである。近年こうした 部分指向の注意特性をもたらす要因として、視覚処理 の特異性、広域への注意の切り替えの困難さといった 実行機能、および群化など知覚体制化の特異性から検 討されてきている。

\section{III. 部分処理特性をもたらす要因}

\section{1. 視覚処理系}

Gepner and Mestre（2002）は、ASD の眼球運動を 分析し、急速視覚運動統合障害 (rapid visual-motion integration deficit）仮説を提唱している。加えて、ASD における知覚的な全体処理、背側視覚経路の処理の 弱さも示唆されている (Milne, Swettenham, Hansen, Campbell, Jeffries, \& Plaisted, 2002; Spencer, O’Brien, Riggs, Braddick, Atkinson, \& Wattam-Bell, 2000)。

小さい文字 (local, 部分) で大きな文字 (global, 全 体）を構成した階層文字刺激を呈示した際、ASD のあ る人は全体レベルよりも部分レベルの文字に対する 反応が優勢であることが知られている (Behrmann, Avidan, Leonard, Kimchi, Luna, Humphreys, \& Minshew, 2006; Plaisted et al., 1999)。この現象の説明 としては、全体刺激が低空間周波数情報で構成される のに対して、部分刺激は高空間周波数情報で構成され るため、低空間周波数処理を担う背側視覚経路の機 能不全により、全体処理が弱まり、ASD では部分処理 が優勢になるというものである (Milne et al., 2002)。 背側視覚経路の機能不全は、ウィリアムズ症候群 (Atkinson, King, Braddick, Nokes, Anker, \& Braddick, 1997) や発達性ディスレクシアのある人 (Cornelissen, Hansen, Hutton, Evangelinou, \& Stein, 1998)にもみら れるが、ASDのある人にのみみられることを示す研究 もある (Tsermentseli, O'Brien, \& Spencer, 2008)。背 側視覚経路の感度を評価するランダムドットキネマト グラムを用いた定型発達者の研究では、ランダムドッ ト上のコヒーレントドットの検出閾值が高いほど社会 的スキルの得点が低く(片桐・河西・室橋, 2007)、LD のある人ではこの検出閾值が高いほど ASD 症状が強 いことが報告されている（片桐・室橋, 2009)。これま での研究結果は、背側視覚経路の機能不全が ASD 特 有のものではなく、初期視覚系の機能不全の結果、複 数の疾患で認められる社会知覚機能などの問題と関係 する可能性を示している（室橋, 2008）。 


\section{2. 実行機能系}

実行機能とは、自分の行動を環境に合わせて適切 にコントロールする機能であり、プランニング、行 動抑制、構えの変更、ワーキングメモリなどを含む。 ASD は反復的で常同的な行動様式を示すことから、実 行機能障害である可能性が指摘されている (Griffith, Pennington, Wehner, \& Rogers, 1999)。実行機能で特 に問題が指摘されている認知的柔軟性（構えの変更） を測定する課題として知られる Wisconsin Card Sorting Test（WCST）では、保続数やカテゴリー達成数など で定型発達者との違いが報告されている (Szatmari, Tuff, Finlayson, \& Bartolucci, 1990)。Ozonoff, Pennington, and Rogers（1991）は、ASD のある人を対象に実行機 能と心の理論との関係を検討し、WCST で誤反応を続 けてしまう保続現象と、第二次誤信念課題の成績の低 さとの間に相関を見いだしたことから、ASDのある人 の実行機能と他者信念の理解の問題とが関係している 可能性を指摘している。さらに認知的柔軟性の問題 は、ASD における注意の解放の問題 (Landry \& Bryson, 2004; Zwaigenbaum, Bryson, Rogers, Roberts, Brian, \& Szatmari, 2005) や注意の切り替えの問題（Mann \& Walker, 2003; Rinehart, Bradshaw, Moss, Brereton, \& Tonge, 2001) とも関連していることも指摘されている。

これまでの ASD のある人を対象とした実行機能研 究では、認知的柔軟性を除いて先行研究の知見が一致 していない。そこで、認知的柔軟性のほか、プランニ ングや抑制、自己モニタリングといつた複数の実行機 能との関連から ASD の臨床特徵を捉え直そうとする 考え方がある (Robinson, Goddard, Dritschel, Wisley, \& Howlin, 2009)。Katagiri, Kasai, Kamio, and Murohashi (2013) は、階層文字刺激を用い、ASD のある人は部分 刺激の反応を繰り返すことで全体刺激への注意の切り 替えが困難になることを報告した。注意を部分から全 体へと切り替えるためには、部分刺激を抑制すること が求められる。ASD のある人は、部分刺激の抑制が難 しく、そのため限局的、反復的な行動傾向と細部へ注 意が焦点化されて部分刺激に対する知覚処理が増強さ れ、全体へ注意を向けるのが困難になっている可能性 がある。すなわち、ASD の細部への注目という特性 は、単に注意の切り替えのみならず、細部処理の抑制 困難など複数の実行機能が関与するといえるだろう。

\section{3. 知覚体制化の特異性}

刺激の小さい要素を大きい形へと統合する群化能力 が弱いと、発達過程で部分処理優位の認知処理スタイ ルが形成されてしまう可能性もある。Scherf, Luna,
Kimchi, Minshew, and Behrmann（2008）は、ASD と 定型発達の学童期、思春期、成人期の各年齢群につい て、部分一全体処理を検討した。階層文字課題を用い た結果では、定型発達群で全体処理が年齢とともに増 大していったが、ASD 群ではこうした効果は認められ ず、部分処理バイアスも認められなかった。さらに、 部分刺激と全体刺激とが干渉し合う不一致条件におい て、ASD 群では干渉効果が認められた。一方、先行刺 激の後にペアで呈示される全体的な形と刺激要素の形 の一致を判断させるプライミングパラダイムを用いた 場合には、特に刺激要素が多い条件において、ASD 群 で部分処理バイアスが認められた。これらの結果は、 多数の刺激要素から刺激全体をまとまりとして知覚す る体制化の能力が、ASD の学童期でも低下しているこ とを示唆する。しかしながら、ASD の知覚体制化を 検討した類似の行動研究では、ASD の部分処理バイ アスは報告されていない (Iarocci et al., 2006; Plaisted, Dobler, Bell, \& Davis, 2006)。事象関連電位を用いた 検討では、カニッツァ図形呈示後約 $150 \mathrm{~ms}$ で惹起さ 孔る後頭部優位の陰性成分 N1の振幅が、就学前後 の ASD のある子どもでは減衰していることが報告さ れている (Stroganova, Orekhova, Prokofyev, Posikera, Morozov, Obukhov, \& Morozov, 2007)。この N1 成分 は、視覚的補完が行わ机たときに惹起される成分であ ることから (Sugawara \& Morotomi, 1991)、N1 の減衰 は知覚体制化の異常を示す所見といえる。しかしなが らこれらの研究から、現段階において知覚体制化の低 下だけでは ASD の部分処理特性を説明し切れていな いのが現状である。

\section{IV. 全体-部分処理特性の関係性}

弱い全体的統合、および充進した知覚機能仮説で は、全体処理が犠牲になる代わりに部分処理が優位に なるというトレードオフの関係を想定していない。す なわち、部分処理も全体処理も独立したメカニズム であることが想定されており (Happé \& Booth, 2008; Katagiri et al., 2013)、部分処理の能力が高いからと いって全体処理の能力が低いとは必ずしもいえない。 しかしながら過剩な部分への焦点化は、全体へと注意 を配分する際の妨げになる。ASD の幼児期の遊びで は、本物の車と見立てて遊ぶのではなくおもちゃの車 の夕イヤを回すといった、細部にこだわった遊びがみ られることがある。ASDのある子どもは随伴性の高い 刺激を好むことから（Gergely, 2001）、車のタイヤと いう一部分に注意を向け、随伴性の高い応答を楽しん 
でいると思われる。人との関わりといった社会的随伴 性が存在する刺激は、結果の予測がしづらい。一方、 随伴性の高い物理的刺激である車の夕イヤは、ASDの ある子どもにとって、より落ち着いて遊びに集中でき るのかもしれない。

生後 12 か月における社会的刺激における定位の弱 さは、ASD とその他の発達障害とを区別するひとつの 指標といえる (Dawson, Webb, Carver, Panagiotides, \& McPartland, 2004)。しかし他方では、部分への注意 が優位なため、細部にこだわり、全体に布置されてい る社会的な刺激に注意が向かないともいえる。その 証左として、ASD のある人は優れた音処理の能力、 特にピッチ記憶、ピッチの弁別、ピッチの方向探索 能力が優れていることが報告されているが (Bonnel, Mottron, Peretz, Trudel, Gallun, \& Bonnel, 2003; Heaton, 2003, 2005; Heaton, Hermelin, \& Pring, 1998; Mottron, Peretz, \& Menard, 2000; O'Riordan \& Passetti, 2006)、その一方でこれらの優れた部分処理は、全体 の声の抑揚、流暢性といった感情を読み取る手がかり を損なう可能性がある。

ASD のある子どもは母親の声や他の社会的な聴 覚刺激に注意を払わず（Dawson, Meltzoff, Osterling, Rinaldi, \& Brown, 1998; Klin, 1991; Kuhl, CoffeyCorina, Padden, \& Dawson, 2005)、非言語音を好むこ とが報告されている（Kuhl et al., 2005）。実際に ASD のある人が他者の声を聞いた際、側頭部位の活動が低 下寸ることが報告されている (Gervais, Belin, Boddaert, Leboyer, Coez, Sfaello, Barthélémy, Brunelle, Samson, \& Zilbovicius, 2004)。声などの社会的な聴覚刺激に対 する選好の度合いは、ASDの言語発達を予測するとさ れ (Paul, Chawarska, Fowler, Cicchetti, \& Volkmar, 2007)、こうした声に対する処理の弱さは、対人相互 交渉の発達に影響を及ぼしている可能性があり注目さ れる。

\section{$\mathrm{V}$. 部分処理と社会的注意行動一模倣障害との関係から}

部分への優れた注意特性は、絶対音感といった優れ た音の処理をもたらし、細部に注意を向ける作業を要 する場合は有利に働く。しかし細部への過度な焦点化 は、社会的な刺激への注意の配分を妨げる可能性もあ る。実際の支援では、部分処理特性を弱めるのではな く、部分へと注意を向けていたのを、いかにしてょり 注意を広げて社会的な刺激へ注意を柔軟に切り替えら れるか、が課題となるだろう。

以前から ASD のある子どもへの社会的注意行動を
促す有力な支援法のひとつとして、模倣を用いた支援 の検討が行われてきた。これは、ASDのある人で指 摘されている運動模倣の問題と相反する (Avikainen, Wohlschlager, Liuhanen, Hanninen, \& Hari, 2003; Ohta, 1987; Rogers, 1999; Rogers \& Pennington, 1991)。近年 では、ASDのある人に全般的な模倣障害は認められな いとする報告がある（Bird, Leighton, Press, \& Heyes, 2007; Hamilton, Brindley, \& Frith, 2007)。Brass, Schmitt, Spengler, and Gergely（2007）は、ASDには 自動的模倣の障害はなく、ロボットアームの動作を人 の動作として自動的に模倣することから非常に強い “animacy bias”があると述べており、むしろ ASD の ある人は、運動模倣の問題よりも自動的な模倣の抑制 に問題があることが指摘されている（Brass \& Heyes, 2005)。これらのことから ASD のある人では、通常の 模倣発達よりも遅れが認められるものの、模倣はASD において決定的な障害ではないといえる。

大人が ASD のある子どもの行為を模倣すると、社 会的な注視行動や相互交渉が増加することが、複数の 研究によって明らかになっている（例えば Dawson \& Adams, 1984; Dawson \& Galpert, 1990)。この相互模倣 による社会的注意行動の促進効果は、知的遅れが軽度 か遅れのない ASD のある 2 歳児、3 歳児においても確 認されている (Katagiri, Inada, \& Kamio, 2010)。人の 行動はASD のある子どもにとって予測不可能な行動 が多いと思われる。相互模倣は自分の行動そのものを 他者が真似ているため、行動の予測が容易である。 ASD のある子どもにとって予測が難しい社会的随伴 刺激が理解し得ない不快な刺激であるならば、ASDの 部分処理特性は、社会的随伴性が存在する刺激に注意 を移さないようにすることで、入力刺激の統制を行つ ていると考えることもできるだろう。

\section{VI. 代償的な認知能力}

顔の処理は、部分ごとのパーツが個別に処理され認 識されるのではなく、目や顔、口をまとめた全体的な 情報を手がかりに認識される。ASD のある人では顔 認知が低下していることが知られており (Weigelt, Koldewyn, \& Kanwisher, 2012)、顔認知に関係する紡 錘状回顔領域の機能低下が報告されている（Schultz, 2005)。さらに、顔刺激により誘発される、事象関 連電位の陰性成分の N170 について、ASD のある 成人で潜時の遅れと振幅の減衰が報告されている (O’Connor, Hamm, \& Kirk, 2005)。N170 は紡錘状回 が信号源として考えられており、これらの知見はASD 
における紡鍾状回での顔処理の異常を示す証拠のひと つとされる。

さらに ASD では、神経的な機能結合の特異性が認 められている。おもに前頭と後頭部位の比較的長い神 経結合の弱さに対して、後頭部位の局所的な神経結合 が強いことが報告されており (Just, Keller, Malave, Kana, \& Varma, 2012)、社会性の問題との関連性が示 唆されている (Vissers, Cohen, \& Geurts, 2012)。顔処 理についていえば、脳の後頭領域に依存する傾向、お よび彼らの脳の前頭領域によって処理されるより大き い認知的・社会的な文脈の処理の弱さを示唆している (Koshino, Kana, Keller, Cherkassky, Minshew, \& Just, 2008)。ASD の優れた視覚探索能力は行動レベルに加 え (O’Riordan, Plaisted, Driver, \& Baron-Cohen, 2001; Plaisted, O'Riordan, \& Baron-Cohen, 1998)、神経科学 的なレベルでも示唆されている。Keehn, Shih, Brenner, Townsend, and Müller（2013）は、視覚探索課題中の 脳活動と機能的神経接合を報告している。彼らは、後 頭部の領域間の局所的な神経結合と後頭-前頭部位を 連絡する神経結合が強いほど ASD の視覚探索能力が 高く、非社会的な課題中の内側前頭前野とコミュニ ケーションスコアとの高い関係は、過剩な注意の焦点 化と関連することを示唆した (Keehn et al., 2013)。さ らに Just et al. (2012) は、ASD での後頭領域での局 所的な神経結合と部分処理特性が密接に関係している ことを指摘している。このことから、克進した部分処 理は優れた視覚処理能力をもたらす一方で、過剩な部 分処理は社会性を司る神経基盤の一部と関係がある可 能性がある。

しかしながら、ASDのある人は必ずしも社会的な刺 激の処理が困難なわけではない。Hadjikhani, Joseph, Snyder, Chabris, Clark, Steele, McGrath, Vangel, Aharon, Feczko, Harris, and Tager-Flusberg (2004) は、参加者に顔刺激の目に注目するように教示して fMRI による脳機能計測を実施したところ、すべての ASD のある人に定型発達者と同様に紡錘状回での活 動が認められた。ASDにおいて紡鍾状回の賦活が認め られたからといって、定型発達者と同様に顔処理をし ている証拠であるとはいい切れないが、定型発達者で は顔処理と直接関係ない脳の神経回路が、ASDのある 人では代償的に顔処理を担っている可能性もあり、注 目される。

社会的刺激の処理には、刺激の要素や全体的な特徵 のみならず、情動や文脈、背景情報など多くの情報を 処理しなければならず、複数の脳領域が処理に関与し
ている。ASDのある人はまったく社会的刺激が処理で きないわけではないことから、何らかの代償的な情報 処理が働いていることが想定される。今後、療育など による介入によって社会的刺激の情報処理がどう促進 するか、またどう代償的に処理されるのか、縦断的な 神経科学的な研究が待たれるところである。加えて、 部分処理特性がぞう適応的に有利、もしくは不利に働 くのか、療育によってどのように部分処理特性、全体 処理特性をバランスよく伸ばしていけるのか、といっ た実践的な研究の積み上げが必要であろう。

\section{VII. 部分処理特性を生かした支援とは}

弱い全体的統合、および充進した知覚機能仮説は、 ASD の優れた知覚や認知特性に注目した理論である。 全体処理特性という適応に有利な認知処理特性の代わ りに発達させた部分処理特性は、感覚入力の刺激を抑 えるという意味では ASD において適応的である一方 で、この特性は社会性の一部に影響を与えている可能 性が示唆される。しかし、部分処理と全体処理の特性 は独立したものであって、トレードオフの関係にはな い。部分処理の優位性をより高めることは、ASD のあ る人の優れた特性を伸ばすことにもつながり、適応义 カニズムのひとつと捉える視点も必要である。前述し た視覚探索がASDのある人で優れているという報告 は、注意の焦点を絞ることで知覚負荷が減少し、無関 連刺激に処理資源がより分配されやすいことによって 生じた結果であるとも解釈できる（河西, 2011）。注意 の焦点化は、情報処理の負荷を軽減させて、刺激が大 量流入して不快閾值を超えないようにする、一種の適 応行動ととらえることもできる。一方で支援の際に は、部分処理特性が周辺の社会的刺激へのアクセスを 弱めてしまう可能性もあり、細部への注意を全体へと 切り替える能力を育てることが必要であろう。

随伴性のある相互模倣を用いて、部分へ滞りがちな 注意を他者へと切り替えるよう促す関わりは、ASDの 発達初期にみられる弱い対人応答性バイアスの修正に 大きく寄与するだろう。実際にこうした関わりは、社 会的な相互交渉で求められるスキルの発達へと波及す る可能性が指摘されている (Whalen, Schreibman, \& Ingersoll, 2006)。知的遅れのある ASD の幼児に対して 相互模倣の訓練を行った研究では、模倣の増加と般 化、さらには言語や社会的行動の増加が認められてい ることから (Ingersoll \& Schreibman, 2006)、早期療 育では特に有効なアプローチといえる。より自然な環 境下で対人的な関係性に焦点をあてた早期療育の方法 
のひとつである Early Start Denver Model には、相互 模倣が実践方法のひとつとして取り入れられており (Rogers, Dawson, \& Vismara, 2012)、対人相互交涉に 関連する認知能力や言語能力の発達促進に成功してい る (Rogers \& Dawson, 2010)。支援者は、子どもの一 つひとつの特性がぞれくらいの能力（強さや弱さ）が あるのかを見極め、特性をうまく生かしながら支援を 行ってゆく必要があり、より一層確かな観察眼とアセ スメント能力が求められるだろう。

\section{謝 辞}

本研究は、日本学術振興会科学研究費補助金若手研 究 B（23730870）による助成を受けた。

\section{文 献}

Atkinson, J., King, J., Braddick, O., Nokes, L., Anker, S., \& Braddick, F. (1997) A specific deficit of dorsal stream function in Williams' syndrome. Neuroreport, 8 , 1919-1922.

Avikainen, S.,Wohlschlager, A., Liuhanen, S., Hanninen, R., \& Hari, R. (2003) Impaired mirror-image imitation in Asperger and high-functioning autistic subjects. Current Biology, 13, 339-341.

Behrmann, M., Avidan, G., Leonard, G. L., Kimchi, R., Luna, B., Humphreys, K., \& Minshew, N. (2006) Configural processing in autism and its relationship to face processing. Neuropsychologia, 44, 110-129.

Bird, G., Leighton, J., Press, C., \& Heyes, C. (2007) Intact automatic imitation of human and robot actions in autism spectrum disorders. Proceedings of the Royal Society B, 274, 3027-3031.

Bölte, S. \& Poustka, F. (2006) The broader cognitive phenotype of autism in parents: How specific is the tendency for local processing and executive dysfunction? Journal of Child Psychology and Psychiatry, 47, 639-645.

Bonnel, A., Mottron, L., Peretz, I., Trudel, M., Gallun, E., \& Bonnel, A. M. (2003) Enhanced pitch sensitivity in individuals with autism: A signal detection analysis. Journal of Cognitive Neuroscience, 15, 226-235.

Brass, M. \& Heyes, C. M. (2005) Imitation: Is cognitive neuroscience solving the correspondence problem? Trends in Cognitive Science, 9, 489-495.

Brass, M., Schmitt, R. M., Spengler, S., \& Gergely, G. (2007) Investigating action understanding: Inferential processes versus action simulation. Current Biology, 17, 2117-2121.

Cornelissen, P., Hansen, P. C., Hutton, J. L., Evangelinou, V., \& Stein, J. F. (1998) Magnocellular visual function and children's single word reading. Vision Research, 38 , 471-482.

Dawson, G. \& Adams, A. (1984) Imitation and social responsiveness in autistic children. Journal of Abnormal Child Psychology, 12, 209-225.

Dawson, G. \& Galpert, L. (1990) Mother's use of imitative play for facilitating social responsiveness and toy play in young autistic children. Development and Psychopathology, 2, 151-162.

Dawson, G., Meltzoff, A. N., Osterling, J., Rinaldi, J., \& Brown, E. (1998) Children with autism fail to orient to naturally occurring social stimuli. Journal of Autism and Developmental Disorders, 28, 479-485.

Dawson, G., Webb, S. J., Carver, L., Panagiotides, H., \& McPartland, J. (2004) Young children with autism show atypical brain responses to fearful versus neutral facial expressions of emotion. Developmental Science, 7, 340-359.

Dawson, G., Webb, S. J., Schellenberg, G. D., Dager, S., Friedman, S., Aylward, E., \& Richards, T. (2002) Defining the broader phenotype of autism: Genetic, brain, and behavioral perspectives. Development and Psychopathology, 14, 581-611.

Gepner, B. \& Mestre, D. (2002) Rapid visual-motion integration deficit in autism. Trends in Cognitive Psychology, 6, 455.

Gergely, G. (2001) The obscure object of desire: 'Nearly, but clearly not, like me': Contingency preference in normal children versus children with autism. Bulletin of the Menninger Clinic, 65, 411-426.

Gervais, H., Belin, P., Boddaert, N., Leboyer, M., Coez, A., Sfaello, I., Barthélémy, C., Brunelle, F., Samson, Y., \& Zilbovicius, M. (2004) Abnormal cortical voice processing in autism. Nature Neuroscience, 7, 801-802.

Grandin, T. \& Johnson, C. (2005) Animals in translation: Using the mysteries of autism to decode animal behavior. Scribner, New York. 中尾ゆかり訳（2006）動物感覚 一アニマル・マインドを読み解く一. NHK 出版.

Griffith, E. M., Pennington, B. F., Wehner, E. A., \& Rogers, S. J. (1999) Executive functions in young children with autism. Child Development, 70, 817-832. 
Hadjikhani, N., Joseph, R. M., Snyder, J., Chabris, C. F., Clark, J., Steele, S., McGrath, L., Vangel, M., Aharon, I., Feczko, E., Harris, G. J., \& Tager-Flusberg, H. (2004) Activation of the fusiform gyrus when individuals with autism spectrum disorder view faces. Neuroimage, 22, 1141-1150.

Hamilton, A. F., Brindley, R. M., \& Frith, U. (2007) Imitation and action understanding in autistic spectrum disorders: How valid is the hypothesis of a deficit in the mirror neuron system? Neuropsychologia, 45, 18591868.

Happé, F. (1999) Autism: Cognitive deficit or cognitive style? Trends in Cognitive Sciences, 3, 216-222.

Happé, F. \& Booth, R. D. (2008) The power of the positive: Revisiting weak coherence in autism spectrum disorders. Quarterly Journal of Experimental Psychology, 61, 50-63.

Happé, F., Briskman, J., \& Frith, U. (2001) Exploring the cognitive phenotype of autism: Weak 'central coherence' in parents and siblings of children with autism. I. Experimental tests. Journal of Child Psychology and Psychiatry, 42, 299-307.

Happé, F. \& Frith, U. (2006) The weak coherence account: Detail-focused cognitive style in autism spectrum disorders. Journal of Autism and Developmental Disorders, 36, 5-25.

Happé, F., Ronald, A., \& Plomin, R. (2006) Time to give up on a single explanation for autism. Nature Neuroscience, 9, 1218-1220.

Heaton, P. (2003) Pitch memory, labelling and disembedding in autism. Journal of Child Psychology and Psychiatry, 44, 543-551.

Heaton, P. (2005) Interval and contour processing in autism. Journal of Autism and Developmental Disorders, 35, 787-793.

Heaton, P., Hermelin, B., \& Pring, L. (1998) Autism and pitch processing: A precursor for savant musical ability? Music Perception, 15, 291-305.

Iarocci, G., Burack, J. A., Shore, D. I., Mottron, L., \& Enns, J. T. (2006) Global-local visual processing in high functioning children with autism: Structural vs. implicit task biases. Journal of Autism and Developmental Disorders, 36, 117-129.

Ingersoll, B. \& Schreibman, L. (2006) Teaching reciprocal imitation skills to young children with autism using a naturalistic behavioral approach: Effects on language, pretend play, and joint attention. Journal of Autism and Developmental Disorders, 36, 487-505.

Just, M. A., Keller, T. A., Malave, V. L., Kana, R. K., \& Varma, S. (2012) Autism as a neural systems disorder: A theory of frontal-posterior underconnectivity. Neuroscience and Biobehavioral Reviews, 36, 1292-1313.

河西哲子 (2011) 自閉症スペクトラム障害の視覚的注 意特性一バイアス化競合モデルによる検討一. 心理 学評論, 54, 29-38.

Katagiri, M., Inada, N., \& Kamio, Y. (2010) Mirroring effect in 2- and 3-year-olds with autism spectrum disorder. Research in Autism Spectrum Disorders, 4, 474-478.

Katagiri, M., Kasai, T., Kamio, Y., \& Murohashi, H. (2013) Individuals with Asperger's disorder exhibit difficulty in switching attention from a local to a global level. Journal of Autism and Developmental Disorders, 43, 395-403.

片桐正敏・河西哲子・室橋春光 (2007) 健常成人にお ける自閉症尺度得点による視覚特性の違い. 電子情 報通信学会技術研究報告, 107, 39-44.

片桐正敏・室橋春光 (2009) LD (学習障害) やLD の 疑いのある人たちにみられる弱い中枢性統合の認知 スタイル. LD 研究, 18, 43-51.

Keehn, B., Shih, P., Brenner, L. A., Townsend, J., \& Müller, R. A. (2013) Functional connectivity for an "Island of sparing" in autism spectrum disorder: An fMRI study of visual search. Human Brain Mapping, 34, 2524-2537.

Klin, A. (1991) Young autistic children's listening preferences in regard to speech: A possible characterization of the symptom of social withdrawal. Journal of Autism and Developmental Disorders, 21, 29-42.

Koshino, H., Kana, R. K., Keller, T. A., Cherkassky, V. L., Minshew, N. J., \& Just, M. A. (2008) fMRI investigation of working memory for faces in autism: Visual coding and underconnectivity with frontal areas. Cerebral Cortex, 18, 289-300.

Kuhl, P. K., Coffey-Corina, S., Padden, D., \& Dawson, G. (2005) Links between social and linguistic processing of speech in preschool children with autism: Behavioral and electrophysiological measures. Developmental Science, 8, F1-F12.

Landry, R. \& Bryson, S. E. (2004) Impaired disengage- 
ment of attention in young children with autism. Journal Child Psychology and Psychiatry, 45, 1115-1122.

Mann, T. A. \& Walker, P. (2003) Autism and a deficit in broadening the spread of visual attention. Journal of Child Psychology and Psychiatry, 44, 274-284.

Milne, E., Swettenham, J., Hansen, P., Campbell, R., Jeffries, H., \& Plaisted, K. (2002) High motion coherence thresholds in children with autism. Journal of Child Psychology and Psychiatry, 43, 255-263.

Mottron. L., Dawson. M., Soulières. I., Hubert. B., \& Burack, J. (2006) Enhanced perceptual functioning in autism: An update, and eight principles of autistic perception. Journal of Autism and Developmental Disorders, 36, 27-43.

Mottron, L., Peretz, I., \& Menard, E. (2000) Local and global processing of music in high-functioning persons with autism: Beyond central coherence? Journal of Child Psychology and Psychiatry, 41, 1057-1065.

室橋春光 (2008) 統合失調症における Magnocellular 系機能をめぐって. 精神保健研究, 21, 63-71.

O'Connor, K., Hamm, J. P., \& Kirk, I. J. (2005) The neuro-physiological correlates of face processing in adults and children with Asperger's syndrome. Brain and Cognition, 59, 82-95.

Ohta, M. (1987) Cognitive disorders of infantile autism: A study employing the WISC, spatial relationship conceptualization, and gesture imitations. Journal of Autism and Developmental Disorders, 17, 45-62.

O'Riordan, M. \& Passetti, F. (2006) Discrimination in autism within different sensory modalities. Journal of Autism and Developmental Disorders, 36, 665-675.

O’Riordan, M. A., Plaisted, K. C., Driver, J., \& BaronCohen, S. (2001) Superior visual search in autism. Journal of Experimental Psychology: Human Perception and Performance, 27, 719-730.

Ozonoff, S., Pennington, B. F., \& Rogers S. J. (1991) Executive function deficits in high-functioning autistic individuals: Relationship to theory of mind. Journal of Child Psychology and Psychiatry, 32, 1081-1105.

Paul, R, Chawarska, K., Fowler, C., Cicchetti, D., \& Volkmar, F. (2007) Listen my children and you shall hear: Auditory preferences in toddlers with autism spectrum disorders. Journal of Speech, Language, and Hearing Research, 50, 1350-1364.

Plaisted, K., Dobler, V., Bell, S., \& Davis, G. (2006) The microgenesis of global perception in autism. Journal of Autism and Developmental Disorders, 36, 107-116.

Plaisted, K. C., O'Riordan, M., \& Baron-Cohen, S. (1998) Enhanced visual search for a conjunctive target in autism: A research note. Journal of Child Psychology \& Psychiatry, 39, 777-783.

Plaisted, K., Swettenham, J., \& Rees, L. (1999) Children with autism show local precedence in a divided attention task and global precedence in a selective attention task. Journal of Child Psychology and Psychiatry, 40, 733-742.

Rinehart, N. J., Bradshaw, J. L., Moss, S. A., Brereton, A. V., \& Tonge, B. J. (2001) A deficit in shifting attention present in high-functioning autism but not Asperger's disorder. Autism, 5, 67-80.

Robinson, S., Goddard, L., Dritschel, B., Wisley, M., \& Howlin, P. (2009) Executive functions in children with autism spectrum disorders. Brain and Cognition, 71, 362-368.

Rogers, S. J. (1999) An examination of the imitation deficit in autism. In J. Nadel \& G. Butterworth (Eds.), Imitation in infancy. Cambridge University Press, Cambridge, UK, 254-283.

Rogers, S. J. \& Dawson, G. (2010) Early Start Denver Model for young children with autism: Promoting language, learning, and engagement. Guilford Press, New York.

Rogers, S. J., Dawson, G., \& Vismara, L. A. (2012) An early start for your child with autism: Using everyday activities to help kids connect, communicate, and learn. Guilford Press, New York.

Rogers, S. J. \& Pennington, B. F. (1991) A theoretical approach to the deficits in infantile autism. Development and Psychopathology, 3, 137-162.

Scherf, K. S., Luna, B., Kimchi, R., Minshew, N., \& Behrmann, M. (2008) Missing the big picture: Impaired development of global shape processing in autism. Autism Research, 1, 114-129.

Schultz, R. T. (2005) Developmental deficits in social perception in autism: The role of the amygdala and fusiform face area. International Journal of Developmental Neuroscience, 23, 125-141.

Shah, A. \& Frith, U. (1993) Why do autistic individuals show superior performance on the Block Design task? Journal of Child Psychology and Psychiatry, 34, 1351- 
1364.

Spencer, J., O’Brien, J., Riggs, K., Braddick, O., Atkinson, J., \& Wattam-Bell, J. (2000) Motion processing in autism: Evidence for a dorsal stream deficiency. Neuroreport, 11, 2765-2767.

Stroganova, T. A., Orekhova, E. V., Prokofyev, A. O., Posikera, I. N., Morozov, A. A., Obukhov, Y. V., \& Morozov, V. A. (2007) Inverted event-related potentials response to illusory contour in boys with autism. Neuroreport, 18, 931-935.

Sugawara, M. \& Morotomi, T. (1991) Visual evoked potentials elicited by subjective contour figures. Scandinavian Journal of Psychology, 32, 352-357.

Szatmari, P., Tuff, L., Finlayson, M. A. J., \& Bartolucci, G. (1990) Asperger's syndrome and autism: Neurocognitive aspects. Journal of the American Academy of Child and Adolescent Psychiatry, 29, 120-136.

Tsermentseli, S., O’Brien, J. M., \& Spencer, J. V. (2008) Comparison of form and motion coherence processing in autistic spectrum disorders and dyslexia. Journal of Autism and Developmental Disorders, 38, 1201-1210.

VanMeter, L., Fein, D., Morris, R., Waterhouse, L., \& Allen, D. (1997) Delay versus deviance in autistic social behavior. Journal of Autism and Developmental Disorders, 27, 557-569.

Vissers, M. E., Cohen, M. X., \& Geurts, H. M. (2012) Brain connectivity and high functioning autism: A promising path of research that needs refined models, methodological convergence, and stronger behavioral links. Neuroscience \& Biobehavioral Reviews, 36, 604625.

Wang, L., Mottron, L., Peng, D., Berthiaume, C., \& Dawson, M. (2007) Local bias and local-to-global interference without global deficit: A robust finding in autism under various conditions of attention, exposure time, and visual angle. Cognitive Neuropsychology, 24, 550-574.

Weigelt, S., Koldewyn, K., \& Kanwisher, N. (2012) Face identity recognition in autism spectrum disorders: A review of behavioral studies. Neuroscience \& Biobehavioral Reviews, 36, 1060-1084.

Whalen, C., Schreibman, L., \& Ingersoll, B. (2006) The collateral effects of joint attention training on social initiations, positive affect, imitation, and spontaneous speech for young children with autism. Journal of Autism and Developmental Disorders, 36, 655-664.

Wing, L. (1997) The autistic spectrum. Lancet, 350, 1761-1766.

Zwaigenbaum, L., Bryson, S., Rogers, T., Roberts, W., Brian, J., \& Szatmari, P. (2005) Behavioral manifestations of autism in the first year of life. International Journal of Developmental Neuroscience, 23, 143-152. - 2012.7.17 受稿, 2014.4.19 受理一 


\title{
Review
}

\section{Perceptual/Cognitive Characteristics and Compensatory Abilities of People With Autism Spectrum Disorders: A Review}

\author{
Masatoshi KATAGIRI \\ Research Center for Child Mental Development, \\ Hamamatsu University School of Medicine \\ (Hamamatsu-Shi, 431-3192)
}

Some individuals with autistic spectrum disorder (ASD) have perceptual/cognitive characteristics that are superior to those of typically developing individuals (TD). In particular, the superior local/detail focus of processing by individuals with autistic spectrum disorder may be an adaptive mechanism for managing what is for them an overabundance of visual information, although there is also a possibility that this local focus may be disadvantageous in social interactions. Based on a review of a large number of findings of recent studies, the present article describes some compensatory abilities and suggests directions for special educational support for individuals with autistic spectrum disorder. The findings of the present review suggest that local and global processing by individuals with autistic spectrum disorder may be independent mechanisms. Support that encourages local processing is not likely to interfere with their social abilities. Rather, people supporting individuals with autistic spectrum disorder should attend to the adaptive aspects of local processing. In addition, it is important to cope with the difficulty that individuals with autistic spectrum disorder have in switching their attention from a local to a global level. Social interactions using imitation may be one of the most effective components of early intervention.

Key Words: local processing, global processing, compensatory abilities, individuals with autistic spectrum disorder (ASD) 